\title{
MIĘDZY ROMANSEM A ORIENTALIZMEM. TYSIĄC I JEDNA OPOWIEŚĆ O MIŁOŚCI
}

Turystyka kobiet do państw rozwijających się połączona z nawiązywaniem relacji intymnych wymyka się prostej definicji seksturystyki. Turystki udające się na wakacje w celach seksualnych stanowią jedną z wielu kategorii kobiet, które podróżują do państw rozwijających się i nawiązują bliższe relacje z lokalnymi mężczyznami. W relacjach tych istotną rolę odgrywa sfera emocjonalna, która uzupełnia wątek seksualny, albo wypełnia całość wzajemnych relacji. Z tego powodu w kontekście turystyki kobiet stosuje się pojęcie turystyki romansu bądź turystyki romantycznej jako pełniej oddającej złożoność relacji między zachodnią turystką a lokalnym mężczyzną ${ }^{1}$. Romans jest w tym sensie marzeniem o urzeczywistnieniu fantazji, która może się ziścić w odmiennym od codziennego - a zatem wyjątkowym - kontekście, jaki oferuje podróż.

Niemiecki portal internetowy „1001 Geschichte” („1001 opowieści”) jest przestrogą, że tego typu marzenia nie mogą się ziścić. Zawiera kilkaset historii miłosnych nadesłanych przez kobiety, które zostały wykorzystane przez mężczyzn wywodzących się z krajów globalnego Południa. Historie te, choć smutne - gdyż żadna się dobrze nie kończy - a niekiedy miejscami tragiczne, wpisują się w struktury narracyjne właściwe dla opisu miłości romantycznej w kulturze zachodniej. Zarazem ze względu na specyficzny kontekst - egzotyczny krajobraz i odmienność kulturową kochanka - stanowią egzemplifikację Saidowskiego orientalizmu. Oba te wymiary - romans i orientalizm - będą przedmiotem niniejszego artykułu.

1 D. Pruitt, S. LaFont, For love and Money. Romance Tourism in Jamaica, „Annals of Tourism Research” 1995, Vol. 22, Nr 2, s. 243. 


\section{Tysiąc i jedna opowieść}

Portal „1001 Geschichte” (http://www.1001-geschichte.de) został założony w 2008 r. przez niemiecką dziennikarkę Evelyn Kern. Wyjechała ona w 1990 r. do Tunezji, gdzie zakochała się w lokalnym mężczyźnie. Ośmioletni związek, który okazał się dla niej koszmarem, opisała w powieści Sand in der Seele (Piasek w duszy, 1998). Portal reklamuje się jako największy tego typu portal w Europie. W specyficznej formie - nadsyłanych opowieści kobiet - z pewnością jest największy, bo jedyny $\mathrm{w}$ swoim rodzaju. $\mathrm{W}$ internecie można jednak znaleźć inne tego typu portale, tyle że w formie forów dyskusyjnych².

„1001 Geschichte” zawiera obecnie około 300 opowieści kobiet, które nawiązały relację intymną z mężczyzną pochodzącym z globalnego Południa (do nielicznych wyjątków należą opowieści nadesłane przez pary lub mężczyzn). Poszczególne opowieści to 1-5-stronicowe autobiografie utrzymane w podobnym stylu - listu do anonimowych czytelników.

Historie kobiet łączą dwa elementy - na początku wielka nadzieja i miłość romantyczna, a na końcu - wielkie nieszczęście i rozczarowanie. W większości przypadków poznani mężczyźni byli (lub mieli być) kochankami czy nawet mężami, nierzadko sprowadzanymi do Niemiec. Po okresie miłosnej euforii kobiety nagle lub stopniowo zauważały zmiany w zachowaniu swoich ukochanych, co prowadziło do zakończenia relacji. Zdarzało się jednak również i tak, że lokalni mężczyźni wyłudzali od nich pieniądze, nie angażując się bezpośrednio w relację intymną, ale oferując zakup fikcyjnej nieruchomości lub pożyczając pieniądze w pilnej potrzebie.

Ponadto na portalu znajduje się wybór książek o przedmiotowej tematyce, a także tzw. czarna lista. Jak tłumaczą właściciele portalu, publiczny dostęp do „czarnej listy” zawierającej nazwiska mężczyzn z kurortów turystycznych znanych ze swoich nieszczerych intencji jest niemożliwy ze względu na ochronę danych osobowych, natomiast za drobną opłatą gotowi są sprawdzić na indywidualną prośbę, czy dana osoba figuruje na tej liście, czy nie.

Do analizy wybrano 205 z 295 opowieści, których podmiotem jest mężczyzna wywodzący się z państwa muzułmańskiego. Są to najczęściej państwa Bliskiego Wschodu i Afryki Północnej znane z masowej turystyki - Egipt, Tunezja i Turcja. To właśnie tam, w lokalnych kurortach dochodziło najczęściej do nawiązywania relacji

$2 \mathrm{Na}$ temat rozlicznych forów internetowych poświęconych turystkom romantycznym por. K. Górak-Sosnowska, M. Klimiuk, Romans czy rodzina? Matżeństwo urfi a wyobrażenia o nim zachodnich turystek w Egipcie, „InterAlia. Pismo poświęcone studiom queer” 2013, nr 8, s. 201-213. 
romantycznych. Nie sposób streścić tu wszystkich opowieści - zresztą nie to jest celem opracowania - zamiast tego warto jednak przytoczyć 10 najczęściej występujących w nich słów, które oddają ich ducha. Grupując je tematycznie, są to słowa wyrażające:

- podmioty relacji (mężczyzna, 'Mann'; kobieta, 'Frau'),

- miejsca akcji (Niemcy, 'Deutschland', mieszkanie, 'Wohnung', hotel, 'Hotel'),

- nadzieje (rodzina, 'Familie', życie, 'Leben', łatwy/prosty 'einfach'),

- emocje (miłość, 'Liebe'),

- i zasadniczy problem (pieniądze, 'Geld').

Można zatem powiedzieć, że są to opowieści o relacjach między nią a nim, próbach i nadziejach na miłość i wspólne życie, na których drodze stoją kwestie finansowe.

Jak wspomniano, dwa dominujące wątki badawcze dotyczą miłości romantycznej i orientalizmu w narracjach autorek opowieści. Początkowo przeanalizowano materiał pod kątem wyodrębnienia dominujących kategorii dyskursu, później zaś wyszczególniono konkretne struktury narracyjne.

Kategorie dyskursu uszeregowano tematycznie, niezależnie od wyodrębionych dwóch wątków kluczowych. Zrezygnowano zarazem z ujęcia chronologicznego, obrazującego etapy związku. Wynika to z dwóch powodów. Po pierwsze, nawiązywane relacje mają co prawda wspólny początek i koniec (od szczęścia do nieszczęścia), jednak zróżnicowany przebieg. O ile okres fascynacji ukochanym prowadzący do ulegnięcia mu można uogólnić, o tyle dalsze losy kobiet są bardzo różne. Niektóre kupowały swoim ukochanym kosztowne podarunki, inne decydowały się na zamieszkanie w kraju ukochanego, spotykając się ze złym traktowaniem ze strony jego lub jego rodziny, u innych problem pojawiał się w momencie, gdy rodziły dziecko, jeszcze inne sprowadzały ukochanego do Niemiec, a następnie nie mogły się z nim rozwieść itp. Po drugie, w ujęciu chronologicznym opowieść urywałaby się na początku drugiej połowy, czyli tuż po ulegnięciu mężczyźnie - finansowym, seksualnym bądź matrymonialnym. Zaraz później rozpoczyna się bowiem opis dramatu, a ten nie mieści się w kategoriach miłości romantycznej.

Wyszczególniono zatem kilka kategorii tematycznych. Pierwsza odnosi się do wątków podróży i egzotyki, które stanowią tło dla nawiązywania relacji romantycznej, a nierzadko są jej katalizatorem. Kolejne trzy kategorie dotyczą przedmiotu miłosnej narracji, czyli ukochanego - jego idealizacji, wyjątkowości oraz przesycenia orientalną egzotyką. Następna kategoria ukazuje miłosne zmagania kobiet w myśl zasady „miłość wszystko zwycięży”. Dwie ostatnie kategorie poświęcone są elementom w zasadzie nieobecnym w narracjach, choć z pewnością obecnych w związkach kobiet z lokalnymi mężczyznami - sferze seksualnej oraz religii/kulturze ukochanych. 


\section{Podróż ku miłości}

Od samego początku miłość romantyczna związana była z nową formą ekspresji - narracją ${ }^{3}$. To nadało jej refleksyjności i zindywidualizowanego charakteru ${ }^{4}$. Podmiot miłotycznej opowieści drążony jest emocjami i wątpliwościami. Autorki opowieści z portalu „1001 Geschichte” wiele miejsca poświęcają na opis i analizę swoich myśli i uczuć:

"«Tonight's the Wight» myślałam sobie - i jeszcze bardzo miło rozmawialiśmy, a potem poprosił mnie, czy mógłby przenocować w moim pokoju, ponieważ jego współlokator już spał i nie miał klucza"s [Mirijam, Tunezja, 60] ${ }^{6}$.

„Czułam się jak nastolatka i nie dostrzegałam jego niecnych zamiarów” [Marlene, Tunezja, 31].

Historie związków kobiet są wyrażane za pomocą kulturowo utartych struktur narracyjnych ${ }^{8}$. Można nawet przypuszczać - jak twierdzi Jessica Jacobs - że zachodnie turystyki konstruują swoje relacje z lokalnymi mężczyznami, nawiązując do znanych im z kultury popularnej wzorców miłości romantycznej9 ${ }^{9}$.

Specyficzne miejsce i sama konieczność podróżowania do niego stwarzają klimat, w którym łatwiej można ulec miłości romantycznej. Podróżowanie wiąże się z niepewnością i ekscytacją, a zatem pobudza psychicznie ${ }^{10}$. Z kolei podróż turystyczna łączy w sobie dwa zasoby niezbędne do rozpoczęcia idealnego romansu: czas wolny i bogactwo ${ }^{11}$, odbywa się bowiem w czasie wolnym od pracy i codziennej rutyny, a ponadto wymaga posiadania odpowiednich zasobów finansowych.

Romantyczna miłość rozgrywa się w specyficznym miejscu - najlepiej w innym niż codzienne otoczenie i podporządkowana jest specjalnym porom, podczas których kochankowie spędzają czas w wyjątkowy sposób. Za ten ostatni aspekt odpowiadają

${ }^{3}$ M. Grzegorek, Przemiany intymności w refleksji socjologicznej. Turystyka Polek w Egipcie jako poszukiwanie miłości, niepublikowana praca magisterska, Instytut Socjologii UW, Warszawa 2010, s. 43.

4 A. Giddens, The Transformation of Intimacy. Sexuality, Love and Eroticism in Modern Societies, Stanford University Press, Stanford 1992, s. 39.

5 „ «Tonight's the night» dachte ich mir - und wir plauderten noch sehr nett, und dann bat er mich noch, ob er in meinem Zimmer übernachten könnte, weil sein Zimmergenosse bereits schliefe und er keine Schlüsselhätte”.

${ }^{6}$ Kolejno podaję pseudonim, miejsce zdarzenia i numer historii.

7 „Ich fühlte mich wie ein Teenager und merkte nicht, was für ein böses Spiel er trieb”.

8 M. Grzegorek, op.cit., s. 44.

9 J. Jacobs, Have sex will travel: romantic 'sex tourism' and women negotiating modernity in the Sinai, „Gender, Place \& Culture” 2009, Vol. 16, Nr 1, s. 44.

10 E. Illouz, Consuming the Romantic Utopia. Love and the Cultural Contradictions of Capitalism, University of California Press, Berkeley 1997, s. 141.

11 E. Illouz, Why Love Hurts. A Sociological Explanation, Polity Press, Cambridge 2012, s. 66. 
lokalni mężczyźni, dostarczając poznanym kobietom zróżnicowanych wrażeń, takich jak spacery po plaży, imprezy w klubach czy zwiedzanie okolicznych atrakcji ${ }^{12}$. Wrażenia te dostarczane są turystkom o specyficznych porach, najczęściej wieczorami:

„[...] spędzał ze mną prawie każdy wieczór, był niesamowicie czuły i czułam się, jak gdybym bujała w obłokach"13 [Sonja, Tunezja, 17].

„I tak pojawił się już następnego dnia i od tego czasu byliśmy każdego wieczora razem”14 [Jenny, Tunezja, 24].

Podczas urlopów czas płynął niezwykle szybko. Zazwyczaj do punktu kulminacyjnego - wyznania uczuć lub skonsumowania związku dochodziło na dzień lub dwa przed wyjazdem:

„Tydzień minął o wiele za szybko i naprawdę zakochałam się w tym małym świrusie i myślałam, że serce mi wyskoczy z piersi, gdy musiałam wsiąść do samolotu"15 [Connie, Tunezja, 29].

„Ostatniego wieczora pożegnałam się z nim. Popatrzył na mnie smutno i znowu mnie zapytał, czy do niego wrócę"16 [Petra, Turcja, 191].

Egzotyczne kurorty nastawione na masowego turystę oferują swoiste "pakiety podróżnicze” - dostosowane do wymogów sektora turystycznego skomodyfikowane krajobrazy, miasta z infrastrukturą, a także obsługę i lokalną ludność ${ }^{17}$. Pakiety oferują homogeniczny produkt zawieszony w bezczasie i poza przestrzenią ${ }^{18}$. Plaże i słońce dodatkowo wzmagają psychologiczne pobudzenie, dostarczając bodźce niewystępujące w codziennym otoczeniu turystów. Bliski nagości strój plażowy jest całkowitym przeciwieństwem ubioru służbowego ${ }^{19}$.

Miejsca, w których dochodzi do zacieśnienia relacji romantycznych, są również szczególne. Jak zauważa Małgorzata Grzegorek, natura sama w sobie stanowi

12 E. Herold, R. Garcia, T. DeMoya, Female Tourists and Beach Boys. Romance or Sex Tourism?, „Annals of Tourism Research" 2001, Vol. 28, Nr 4, s. 987.

13 „[...] er verbrachte fast jeden Abend mit mir, war ungeheuer zärtlich und ich hatte das Gefühl auf Wolken zu schweben".

14 „So, schon am nächsten Tag war er da und von da an, waren wir jeden Abend zusammen”.

15 „Die Woche ging viel zu schnell vorbei und ich habe mich wirklich in den kleinen Verrückten verliebt und glaubte man reiße mir das Herz aus der Brust als ich ins Flugzeug steigen musste".

16 „Am letzten Abend verabschiedete ich mich von ihm. Er sah mich traurig an und fragte mich wieder, ob ich zu ihm zurückkommen werde".

${ }_{17}$ E. Illouz, Consuming the Romantic Utopia..., op.cit., s. 97.

18 J. Scott, T. Selwyn, Introduction. Thinking through Tourism - Framing the Volume, w: Thinking through Toursim, red. J. Scott, T. Selwyn, Berg, Oxford 2010, s. 4.

19 E. Illouz, Consuming the Romantic Utopia..., op.cit., s. 99. 
romantyczną scenerię, w której może dojść do uwolnienia autentycznego „ja” ${ }^{20}$. Natura oznacza bowiem kontakt z dzikością, przeciwstawianą cywilizacji otaczającej kobiety w ich naturalnym środowisku ${ }^{21}$. Miejscem akcji wakacyjnych romansów były zatem miejsca związane z naturą, morze i plaża:

„Tak, przez dwa tygodnie siedziałam z Muratem na plaży w Tunezji i jeszcze nigdy nie byłam tak zakochana"22 [Jenny, Tunezja, 24].

„Dzień przed moim wyjazdem spędziłam z nim noc na plaży”23 [Rosemarie, Tunezja, 3].

Krajobraz przenika bliskowschodnich kochanków w taki sposób, że staje się komplementarnym obiektem fascynacji zachodniej turystki ${ }^{24}$. Egzotyka kojarzona jest $\mathrm{z}$ rajem, w którym poprzez kontakt $\mathrm{z}$ naturą w jej czystej i nieskazitelnej formie można odnaleźć autentyczność i czystość ${ }^{25}$.

„Bezpośredni kontakt z piękną naturą sprawiał, że byłam przeszczęśliwa. To było fantastyczne”26 [Frei, Egipt, 221].

„Jesteśmy zafascynowane duchowymi przeżyciami na pustyni, związkiem z naturą [...]”27 [Vier Frauen, Maroko, 228].

Jak się okaże, kontakt $\mathrm{z}$ naturą jest także jednym z elementów ułatwiających nawiązanie przez kobiety relacji intymnej z lokalnym mężczyzną, który - jako przedstawiciel ludności lokalnej, element „pakietu podróżniczego” - również daje poczucie zbliżenia się do natury i autentyczności.

\section{Idealizacja partnera}

Idealizacja partnera jest jednym z najistotniejszych elementów składowych miłości romantycznej ${ }^{28}$. Charakterystyka bliskowschodnich kochanków - zarówno ich

${ }^{20}$ M. Grzegorek, op.cit., s. 35.

${ }^{21}$ E. Illouz, Consuming the Romantic Utopia..., op.cit., s. 137.

22 "Tja, zwei Wochen lang saß ich mit Morath so am Strand in Tunesien und noch nie war ich so verliebt”.

23 "Einen Tag vor meiner Abreise, verbrachte ich die Nacht mit ihm am Strand”.

${ }^{24}$ J. Jacobs, op.cit., s. 44.

${ }^{25}$ E. Illouz, Consuming the Romantic Utopia..., op.cit., s. 140.

26 „Der direkte Kontakt mit der schönen Natur machte mich überglücklich. Es war fantastisch”.

27 "Wir sind fasizniert vom spirituellen Erleben in der Wüste, der Verbundenheit mit der Natur [...]”.

28 V. Hefer, op.cit., s. 22. 
wyglądu zewnętrznego, jak i cech charakteru - zajmuje sporo miejsca w niemalże każdej opowieści. Wyidealizowane opisy pojawiają się na początku historii jako element służący do doprowadzenia akcji do pierwszego punktu kulminacyjnego - miłości od pierwszego wejrzenia. Bliskowschodnim mężczyznom przypisywane są wręcz nadludzkie cechy, a zarazem niepowtarzalność i wyjątkowość:

„Był jak sen moich nieprzespanych nocy. Duży. Ciemny, dobrze zbudowany, lśniące białe zęby i do tego lśniący uśmiech"29 [Cornelia, Tunezja, 5].

„Ali był dwa lata młodszy ode mnie i był to najlepiej wyglądający mężczyzna, jakiego kiedykolwiek widziałam. Pracował w moim hotelu w obsłudze i był obiektem westchnień wszystkich kobiet. Nie mogłam wówczas zrozumieć, dlaczego chciał właśnie mnie [...]”30 [Lisa, Tunezja, 8].

Idealizacja partnera pełni dodatkowo funkcję instrumentalną. Pozwala bowiem autorkom narracji na swoiste nurzanie się w tym ideale ${ }^{31}$. Widać to zwłaszcza w drugim cytacie, gdzie autorka jest wyraźnie podekscytowana tym, że spośród wszystkich innych kobiet obiekt jej westchnień i fascynacji wybrał właśnie ją.

Bliskowschodni kochankowie, podobnie jak karaibscy opisywani przez Herolda, Garcię i DeMoya, zdobywają serca zachodnich turystek, zachowując się w sposób subtelny i uroczy oraz poświęcając im dużo uwagi i atencjii ${ }^{32}$ :

„Mój Farhat był najukochańszym człowiekiem na świecie, wszystko dla mnie robił. Stawał na głowie, aby sprawić mi przyjemność. Przy tym był tak cudownie uroczy, tak czuły i pełny

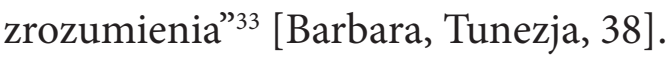

„To był sen taki, jakim go zawsze śniłam. Nigdy nie oczekiwałam tak dużo opiekuńczej czułości i empatii” ${ }^{34}$ [Veronika, Tunezja, 76].

${ }^{29}$ „Er war der Traum meiner schlaflosen Nächte. Gross. Dunkel, gut gebaut, strahlend weisse Zähne und noch ein strahlendes Lächeln".

30 „Ali war zwei Jahre jünger also ich und der best aussehende Mann, den ich jemals gesehen hatte. Er arbeitete in meinem Hotel im Service und war der Schwarm aller Frauen. Dass er ausgerechnet mich wollte, konnte ich damals gar nicht verstehen [...]".

${ }^{31}$ M. Grzegorek, op.cit., s. 31.

32 E. Herold, R. Garcia, T. DeMoya, op.cit., s. 986.

33 „Mein Farhat was der liebste Mensch der Welt, er tat alles für mich. Er riss sich fast die Arme und Beine aus, um mir einen Gefallen zu tun. Dabei was er auch noch so wunderbar charmant, so zärtlich und verständnisvoll".

34 „Es war ein Traum, wie ich ihn immer geträumt hatte. So viel behutsame Zärtlichkeit und Einfühlungsvermögen hätte ich niemals erwartet”. 
Czułość, opiekuńczość, grzeczność i urok to cechy, dzięki którym bliskowschodni mężczyźni podtrzymują i intensyfikują swoje kontakty z zachodnimi kobietami. Są to zarazem te cechy, których brakuje kobietom w relacjach z mężczyznami z ich kręgu kulturowego ${ }^{35}$. W tym sensie bliskowschodni kochankowie wypełniają emocjonalną lukę, zwłaszcza że zachodnie turystki kierują się przede wszystkim uczuciem miłości, gdy podejmują decyzję o zacieśnieniu relacji intymnej ${ }^{36}$; warto dodać, że jest to miłość absolutna:

„Tak bardzo za nim tęskniłam, że nie mogłam ani jeść, ani spać, a jak w końcu znalazłam się w jego ramionach, byłam najszczęśliwszym człowiekiem na ziemi”"37 [Marion, Tunezja, 47]. „Zakochałam się po uszy. Bujałam w obłokach, byłam przeszczęśliwa i myślałam, że bez niego umrę"38 [Mandy, Tunezja, 45].

Przytoczone cytaty podkreślają intensywność uczuć. Ta intensywność wynika nie tylko z siły i skuteczności oddziaływania bliskowschodnich kochanków, ale również ze specyficznych cech kobiet będących obiektami ich romantycznych uniesień. Ponownie warto sięgnąć do badań Herolda, Garcii i DeMoya, w których autorzy opisują sposoby ustalania celu romantycznych adoracji przez lokalnych mężczyzn. Są to najczęściej starsze kobiety, albo młodsze z pewnym mankamentem w wyglądzie. Wiek i wygląd to cechy, na podstawie których mężczyźni wnioskują, że dana kobieta szybciej ulegnie miłości romantycznej i/lub będzie bardziej gotowa do zaangażowania się finansowego w związek. Mogą bowiem przypuszczać, że nie są one przyzwyczajone do tego, aby ktoś poswięcał im swoją uwagę ${ }^{39}$. Wątek ten pojawia się zresztą w opowieściach Niemek:

„W międzyczasie zakochałam się po uszy w Baszszarze. W Niemczech nigdy by mi się to nie przytrafiło. Ale w Niemczech nikt by mnie nie wziął, kto wziąłby niepełnosprawną i niespecjalnie ładną kobietę?" ${ }^{40}$ [Katrin, Tunezja, 28].

35 J. Jacobs, op.cit., s. 65.

${ }^{36}$ F. Tschanz-Kassem, Bezness in Hurghada, niepublikowana praca magisterska, Schweizerische Tourismusfachschule, Siders 2007, s. 48.

37 "Ich hatte ihn so sehr vermisst, dass ich weder essen noch schlafen konnte und als ich dann endlich in seinen Armen lag, war ich der glücklichste Mensch der Welt".

38 „Ich verliebte mich Hals über Kopf in ihn. Ich schwebte auf Wolken, war überglücklich und dachte ich müsste sterben ohne ihn".

39 E. Herold, R. Garcia, T. DeMoya, op.cit., s. 985.

40 „Inzwsichen hatte ich mich bis über beide Ohren in Bechir verliebt. In Deutschland wäre mir das nie passiert. Aber in Deutschland hätte mich auch niemand genommen, wer nimmt schon eine behinderte nicht sehr hübsche Frau". 
„Nagle poczułam się obiektem pożądania, było to uczucie, którego nigdy przedtem nie doznałam"41 [Margot, Tunezja, 206].

Bliskowschodni kochankowie dają (czy raczej zdają się dawać) zachodnim turystkom to, czego nie doświadczyły w swoich krajach, spełniając ich marzenia o miłości romantycznej. Tymczasem w świecie zachodnim już dawno obwieszczono kres miłości od pierwszego wejrzenia do grobowej deski, zastępując ją chociażby ideą miłości współbieżnej - partnerskiej, opartej w dużej mierze na racjonalnych kryteriach i świadomych decyzjach. Miłość romantyczna zdaje się również nie mieścić w dyskusjach o równouprawnieniu kobiet i mężczyzn. Z tych powodów zachodnie turystki cenią sobie i podkreślają, że przy swoich bliskowschodnich partnerach mogą czuć się jak kobiety ${ }^{42}$ :

„Bardzo dobrze czułam się przy nim jako «kobieta»"43 [Desertrose, Egipt, 138].

„14 dni minęło w locie i poczułam się znowu atrakcyjna i kobieca”44 [Brucefan, Tunezja, 220].

Aby jednak kobiety mogły czuć się jak prawdziwe kobiety, muszą mieć u swojego boku prawdziwego mężczyznę. W tym miejscu ponownie warto odnieść się do kontekstu zachodniego - przemian i towarzyszących im konfuzji w zakresie postrzegania płci i seksualności. W bliskowschodnich kurortach kobiety mogą się w pełni odciąć od tych dylematów ${ }^{45}$.

\section{Ten jeden jedyny}

Przekonanie o tym, że wybranek jest tym jednym, jedynym i na zawsze jest jednym z podstawowych elementów składowych wzorca miłości romantycznej obecnego w zachodniej kulturze ${ }^{46}$.

\footnotetext{
41 "Ich fühlte mich plötzlich begehrenswert, das war ein Gefühl wie ich es vorher niemals hatte”.

${ }^{42}$ F. Tschanz-Kassem, op.cit., s. 40.

43 "Ich habe mich bei ihm als «Frau» sehr wohl gefühlt".

44 "Die 14 Tage vergingen wie im Flug und ich fuehlte mich wieder attraktiv und weiblich".

45 J. Jacobs, op.cit., s. 53.

${ }^{46}$ A. Giddens, op.cit., s. 61.
} 
„Ściskał moją rękę coraz mocniej, patrzył na mnie swoimi wspaniałymi oczami z coraz większym uczuciem i w końcu mnie pocałował, tak namiętnie [...]. Byłam całkowicie wkręcona; wiedziałam - ten albo żaden inny" ${ }^{\text {"47 }}$ [Jessie 27, Tunezja, 61].

„Od tego czasu codziennie się widzieliśmy. Powstała z tego miłość. Traktował mnie jak księżniczkę i cały czas był przy mnie. Bardzo się kochaliśmy. Dawno nie przeżyłam czegoś tak romantycznego i pięknego. Uczucie szczęścia i beztroski. Myślałam, że jest to miłość mojego życia" ${ }^{48}$. [Natalie, Maroko/Niemcy, 142].

Proces zakochania prowadzący kobiety do przekonania, że wybranek jest miłością ich życia, podkreśla przede wszystkim aspekty emocjonalne. Miłość romantyczna usuwa bowiem na bok ziemskie, fizyczne doznania, kładąc nacisk właśnie na sferę uczuciową - pokrewieństwo duchowe kochanków ${ }^{49}$, które docelowo ma prowadzić do ich jedności. Taka „emocjonalna telepatia” oznacza zanik wszelkich barier i różnic między kochankami ${ }^{50}$. Również ten aspekt podkreślały kobiety w swoich narracjach:

„Potem przytulaliśmy się całkiem długo i przyrzekliśmy sobie, że nigdy się nie rozstaniemy, niezależnie od tego, co by się wydarzyło. Był moim duchowym powiernikiem ${ }^{\text {“51 }}$ [Alexz, Tunezja, 153].

„Żadne małżeństwo nie było tak szczęśliwe i harmonijne jak nasze. Ali i ja bardzo się kochaliśmy. Byliśmy nierozłączni, spędzaliśmy razem dni i noce, i tak było przez dwa lata"52. [Karla, Egipt/Niemcy, 12].

„Mówił trochę po niemiecku, a także nieco po angielsku i tak mogliśmy się całkiem dobrze porozumiewać. Bardzo miło się z nim rozmawiało i miał wspaniałe poglądy na temat rodziny i partnerstwa, mówił o zaufaniu i miłości i że nigdy nie zrozumie, jak mężczyzna może opuścić swoją rodzinę, czy nią poniewierać"53 [Sandra 2, Tunezja, 41].

47 „Er ergriff meine Hand immer stärker, schaute mich immer lieber mit seinen tollen Augen an, auf einmal küsste er mich, so leidenschaftlich [...]. Ich war hin und weg; ich wusste der oder keiner".

48 „Von da an sahen wir uns jeden Tag. Es wurde Liebe daraus. Er behandelte mich wie eine Prinzessin und war die ganze Zeit für mich da. Wir liebten uns innig. So etwas Romantisches und Schönes hatte ich schon lange nicht mehr gehabt. Das Gefühl einfach glücklich und geborgen zu sein. Er nahm mich auch so wie ich war. Ich dachte das ist die Liebe meines Lebens".

49 Ibidem, s. 45.

50 M. Grzegorek, op.cit., s. 31.

51 „Danach kuschelten wir ganz lange und schworen und, einander nie zu verlieren, egal was passieren wuerde. Er war mein Seelenverwandter".

52 „Wohl kaum eine Ehe war so gluecklich und harmonisch wie unnsere. Ali und ich liebten uns sehr. Wir konnten niemals die Finger voneinander lassen, Tag und Nacht waren wir zusammen und das alles zwei Jahre lang".

53 „Er sprach ein wenig deutsch aber auch ein bisschen englisch und wir konnten uns so ganz gut verständigen. Es war sehr nett mit ihm zu plaudern und er hatte tolle Ansichten über Familie und Partnerschaft, sprach von Vertrauen und Liebe und dass er es niemals verstehen koennte, wenn Männer ihre Familie vernachlässigen oder gar misshandeln würde". 
Duchowe powinowactwo dostrzegały kobiety w różnych aspektach swojego związku. W pierwszym cytacie związek dusz ma charakter absolutny $\mathrm{i}$ - w połączeniu z przysięgą - w największym stopniu wpisuje się w kanon miłości romantycznej. W przypadku drugim jedność dotyczy życia codziennego. Najciekawszy wydaje się trzeci cytat. Z jednej strony kobieta pisze o niewielkiej znajomości języków obcych swojego partnera i związanych z tym trudnościach komunikacyjnych, z drugiej zaś o tym, jak połączyły ich wspólne rozmowy.

\section{On, „Orientalczyk”}

Przedmiotem narracji w analizowanych opowieściach z portalu „1001 Geschichte” są mężczyźni mieszkający w państwach muzułmańskich lub wywodzący się z nich. Narracje te oparte są na dwóch fundamentach. Pierwszym są wyobrażenia na temat romantycznego kochanka, które nakładane są na wygląd, cechy charakteru i zachowanie mężczyzn. Drugi związany jest ze specyfiką kulturową Bliskiego Wschodu - miejsca akcji większości opisywanych wakacyjnych romansów.

Badania Franziski Tschanz-Kassem wskazują na to, że kobiety nawiązujące relacje intymne z lokalnymi mężczyznami nie szukają egzotyki. To, że ich kochanek pochodzi z odmiennej, egzotycznej kultury zdaje się nie mieć dla nich znaczenia ${ }^{54}$. Tymczasem w opisach mężczyzn na portalu „1001 Geschichte” stosunkowo często można znaleźć odniesienia do orientalnej egzotyki. Niektóre bywają subtelne, np.:

„On, 26-latek z oczami niczym kuskus, zmysłowymi erotycznymi ustami, oczarował mnie swoim wdziękiem i sztuką kulinarną" ${ }^{55}$ [Anita, Maroko, 64].

„Gdy po raz pierwszy go ujrzałam, byłam całkowicie zafascynowana tym mężczyzną; emanował jak nic na tym świecie; żaden szmaragd nie mógłby promieniować jak jego oczy”56 [Jessie 27, Tunezja, 61].

${ }^{54}$ F. Tschanz-Kassem, op.cit., s. 39.

55 „Er mit seinen 26 Jahren und seinen Couscous-Augen, mit erotischen sinnlichen Lippen, hat mich mit seinem Charme und seinen Kochkünsten verzaubert".

56 „Als ich ihn das erste Mal sah, war ich total fasziniert von diesem Mann; er hatte Ausstrahlung, die man mit nichts auf dieser Welt vergleichen konnte; kein Smaragd könnte so strahlen, wie seine Augen damals". 
W obu cytatach kobiety odnoszą się do oczu mężczyzn ${ }^{57}$, przyrównując je do czegoś, co kojarzą z Bliskim Wschodem. O ile szmaragdy można wydobywać w różnych miejscach na świecie, to jednak jako cenny kamień jubilerski używany w starożytnym Egipcie i w Arabii przywołują skojarzenia z orientalnym luksusem. Nieco trudniejsze do interpretacji wydaje się skojarzenie drugie - z kuskusem, gdyż najpewniej nie chodzi o rozmiar oczu, ani o kształt, ale i odniesienie do koloru wydaje się mało prawdopodobne. Być może zatem jest to zabieg stylistyczny, którego celem jest nadanie narracji orientalnego klimatu.

Inne narracje podkreślają wprost egzotyczny charakter bliskowschodnich kochanków:

„Był czarujący i zakochałam się w nim. Sen z 1001 nocy”58 [Marielousie, Maroko, 202].

„Był tak kruchy, a jego piękne, egzotyczne, typowo egipskie oczy wywarły na mnie olbrzymie wrażenie" ${ }^{259}$ [Frei, Egipt, 224].

Cytat pierwszy nie tylko wpisuje się w orientalną baśniową stylistykę zilustrowaną wyżej, ale w zasadzie bezpośrednio się do niej odnosi. Kobiety są zafascynowane lub zaczarowane obiektami swojej miłości, które jawią się im niczym marzenie senne. Marzenie to opiera się na baśniowych obrazach relacji miłosnych znanych chociażby z Księgi 1001 nocy, czy relacji XIX-wiecznych podróżników ${ }^{60}$. Potwierdzają to inne narracje, których autorki opisują, że były traktowane jak księżniczki.

Wyobrażenia o Oriencie uzupełnia cytat drugi, o typowo egipskich oczach. Przykłady te wskazują na swoiste urasowienie seksualności. Pojęcie to wprowadził amerykański literaturoznawca Abdul Jan Mohamed. Przełamując tabu związane z kontaktem seksualnym osób o innej etniczności lub rasie, niesie ona ze sobą potencjał erotyczny ${ }^{61}$. Autorki narracji budują swoje opisy bliskowschodnich mężczyzn, odnosząc się do cech wynikających ze stereotypu orientalnego partnera, który jest egzotyczny (co mówią wprost, albo pośrednio), czarujący, a zarazem dziki i (domyślnie) hiperseksualny.

57 Jak wskazują Herold, Garcia i DeMoya, to właśnie poprzez utrzymywanie intensywnego kontaktu wzrokowego mężczyźni starają się zainteresować sobą zachodnie turystki - por. E. Herold, R. Garcia, T. DeMoya, op.cit., s. 985.

58 "Er war zauberhaft und ich verliebte mich. Ein Traum aus 1001 Nacht”.

59 "Ich fand ihn so zerbrechlich und seine wunderschönen, exotischen, typisch ägyptischen, Augen, beeindruckten mich so sehr".

60 J. Jacobs, op.cit., s. 44.

${ }^{61}$ L. Williams, Skin Flicks on the Racial Border. Pornography, Exploitation and Interracial Lust, w: Porn Studies, red. L. Williams, Duke University Press, London 2004, s. 275. 


\section{Miłość wszystko zwycięży}

Ten aspekt miłości romantycznej ${ }^{62}$ widoczny jest przede wszystkim w przebiegu akcji. Opowieści romantyczne mają ściśle określoną formę - wartka akcja, wydarzenia następują szybko po sobie i niosą ze sobą dużą dawkę emocji. Nieodzownym elementem narracji są przeciwności losu, które uniemożliwiają kochankom spełnienie ich marzeń o wspólnym związku' ${ }^{63}$.

Struktura ta znajduje odzwierciedlenie w opowieściach kobiet. Narracje mają bowiem w większości podobną strukturę. Początkowo opisywane jest miejsce akcji (najczęściej wakacyjne), następnie On - jego wygląd i charakter, sposób nawiązania znajomości, a także uczucia temu towarzyszące. Pierwszym punktem kulminacyjnym jest wyznanie uczuć i zapewnienie o gotowości do nawiązania stałej relacji. Zaraz po tym autorka przechodzi do fazy późniejszej, opisującej narastające trudności w podtrzymaniu relacji i rosnące negatywne emocje. Drugim punktem kulminacyjnym a zarazem rozwiązaniem akcji jest zakończenie relacji z mężczyzną spowodowane jego zniknięciem, albo zerwaniem jej przez kobietę.

Figura „miłość wszystko zwycięży” pojawia się między obiema fazami relacji. Jeżeli przypisana jest raczej do fazy początkowej - odnosi się do wyobrażeń o potencjalnych trudnościach związanych z różnicami międzykulturowymi i generacyjnymi, które jednak najczęściej kobiety same rozwiewały:

„Powiedziała mi [przyjaciółka - przyp. K.G.S.], że nie słyszała niczego dobrego o związkach osób różnych narodowości i że najczęściej nic z nich nie wychodzi. Nie wierzyłam jej. Mustafa nie był osobą, która mogłaby ciemiężyć kobietę, był po prostu kochany"64 [Nadine, Maroko, 18].

„Najpierw nie mogłam w to [że się we mnie zakochał - przyp. K.G.S.] uwierzyć, ponieważ Mohamed był przystojny, a ja - no cóż - pulchnawa i niekoniecznie piękna, raczej przeciętna. A także dziewięć lat starsza od niego" ${ }^{35}$. [Rosemarie, Tunezja, 3].

${ }^{6}$ V. Hefer, From Love at First Sight to Soul Mate: Romantic Ideals in Popular Films and their Association with Young People's Beliefs about Relationships, niepublikowana praca doktorska, University of Illinois at Urbana-Champaign, Urbana 2011, s. 22.

${ }^{63}$ E. Illouz, Consuming the Romantic Utopia..., op.cit., s. 169.

64 "Sie erzählte mir, dass sie von solchen binationalen Beziehungen nichts Gutes gehört hat und dass sie meist schief gehen. Das glaubte ich nicht. Mustafa war nicht so ein Typ, der eine Frau unterdrucken würde, er war einfach nur lieb".

65 „Zunächst konnte ich das nicht glauben, denn Mohamed war ein gutaussehender Mann und ich, na ja, schoen etwas pummelig und nicht gerade eine Schönheit, eher ein Allerweltstyp. Und ja auch neun Jahre älter als er". 
„Dobrze, Ali był 12 lat młodszy ode mnie, ale mając 41 lata, nie byłam jeszcze wcale stara, wyglądałam całkiem dobrze, tak że nie musiałam się wstydzić”66 [Martha, Tunezja, 21].

Różnice międzykulturowe czy uprzedzenia związane z islamem są rzadko przytaczane przez kobiety. Jeżeli się pojawiają, to głównie w kontekście ostrzeżeń innych osób, które zauroczone autorki najczęściej bagatelizowały. Znacznie częściej przedmiotem rozważań jest różnica wieku (nawiązania do niej występują w kilkudziesięciu opowieściach). Niektóre kobiety poprzestają na podaniu wieku swojego i partnera, często jednak różnica wieku jest komentowana - jak w powyższych przykładach. Większość kobiet zdaje sobie sprawę z tego, że różnica wieku działa na ich niekorzyść (mimo to starają się ją bagatelizować), jedynie kilka uznało, że mimo to są wystarczająco atrakcyjne dla swoich partnerów.

Jeżeli figura „miłość wszystko zwycięży” pojawiała się w fazie drugiej, ukazuje narastające trudności. Pojawiają się tu takie słowa, jak „praca” ('Arbeit'; zazwyczaj „brak pracy”, 'keine Arbeit' - wskazując na niechęć albo niemożność znalezienia pracy przez mężczyzn), „opłacać, opłacony, opłaciłam” ('bezahlen', 'bezahlte', 'bezahlt'; opisy dotyczyły tego, że kobiety musiały wszystko opłacać, gdyż ich kochankowie nie mieli pieniędzy).

Początkowo kobiety chętnie pokrywały nie tylko koszty wspólnych spotkań, ale również bieżące wydatki swoich partnerów. Z opowieści autorek wynika, że mężczyźni rzadko prosili je wprost o pieniądze - raczej same uznawały, że wesprą go, a czasami nawet jego rodzinę, ponieważ dysponują nieporównywalnie większymi zasobami ekonomicznymi. Takie odwrócenie tradycyjnych ról społecznych związanych z płcią (gdyż tradycyjnie to mężczyzna zapewnia rodzinie środki finansowe) dawało im poczucie kontroli sytuacji i nowe doznania ${ }^{67}$. Podstawą do tego typu odwrócenia ról jest kontekst ekonomiczny. Kobiety pochodzą z bogatych krajów Północy i udają się do ubogich państw globalnego Południa, w których masowa turystyka jest nierzadko jednym z najważniejszych źródeł dewiz. Poznawani mężczyźni są zazwyczaj zawodowo związani bezpośrednio (kelnerzy, animatorzy) albo pośrednio (sprzedawcy na okolicznych targach) z sektorem turystycznym. Ich niższe zarobki wynikają zatem nie tylko z luki w poziomie rozwoju gospodarczego Północy i Południa, ale często również miejsca w strukturze zawodowej.

Prawa miłości romantycznej pozwalają na zakwestionowanie różnic nie tylko narodowych, ale i klasowych ${ }^{68}$. Z tego powodu kobiety początkowo godzą się na pełnienie

66 „Gut, Ali was 12 Jahre jünger als ich, aber ich war mit meinen 41 Jahren noch keine alte Frau und sah noch gut aus, so dass ich mich nicht schämen musste”.

67 E. Herold, R. Garcia, T. DeMoya, op.cit., s. 991.

68 M. Grzegorek, op.cit., s. 33. 
roli sponsora, a później przeżywają rozczarowanie, gdy okazało się, że zostały wykorzystane, oszukane i były - jak same nieraz przyznają - jedynie „środkiem do osiągnięcia celu” ('Mittel zum Zweck'):

„Byłam tak zrozpaczona i zaszokowana, że nie było nigdy tej «miłości», tylko kłamstwo z zimnym wyrachowaniem"69 [Nette, Turcja, 133].

„Było pewne, że chciałam zakończyć tę farsę z małżeństwem, ponieważ mój mąż od samego początku tylko mnie wykorzystywał, a wszystkie jego przyrzeczenia miłości byly jedynie kłamstwem i środkiem do osiągnięcia celu"70 [Doris, Kosowo/Niemcy, 14].

Po etapie rozczarowania i goryczy następują niekiedy dramatyczne opisy działań podejmowanych przez kobiety, mających na celu uwolnienie się z nieszczęśliwej realcji. Wszystkim autorkom opowieści udaje się w końcu ten cel osiągnąć. Niektóre nadal mają niepokój psychiczny, inne puentują opowieść krótką wzmianką o swoim obecnym życiu. W tym sensie opowieści - choć tragiczne - kończą się w zdecydowanej większości happy endem.

\section{A gdzie seks?}

Słowo „seks” ('Sex’) pojawia się zaledwie 45 razy, a innych słów określających stosunek płciowy w zasadzie nie ma (zwłaszcza tych ordynarnych) w opowieściach. Autorki używają słowa „seks” nie tyle w odniesieniu do swoich doznań, co raczej do opisu norm moralnych - swoich bądź partnera:

„Był super słodki, nauczył mnie wszystkiego o swoim kraju i był taki przyzwoity! (Seks dopiero po ślubie!!)"”1 [Tanja, Maroko/Niemcy, 216].

„Byłam całkowicie przeciwna seksowi w ramach wakacyjnych flirtów, ale tak bardzo się zakochałam, a i wydawało się, że on do mnie coś czuł [...]”72 [Wicky, Tunezja, 114].

${ }^{69}$ „Ich war so verzweifelt und geschockt darüber, dass ja diese «Liebe» nie wirklich gewesen ist, sondern alles nur Betrug mit kalter Berechnung".

70 „Fest stand, dass ich diese Farce von einer Ehe beenden wollte, denn mein Mann hatte mich von Anfang an nur benutzt und all seine Liebesschwüre und schönen Worte waren nur Lüge und Mittel zum Zweck".

71 „Er war super süß, brachte mir alles über sein Land bei und war ja so anständig! (Sex erst in der Ehe!!)”.

72 "Ich war total gegen Sex mit Urlaubsflirts, aber ich habe mich doch so verliebt und er schien ja auch etwas für mich zu empfinden [...]". 
Własne życie erotyczne opisują nie wprost, ale stosując niedopowiedzenia, tak jakby ta sfera relacji z ich bliskowschodnimi kochankami nie była kluczowa:

„Kilka dni później przyprowadził mnie do mieszkania. Siedział przede mną nieśmiały i w końcu zaczął mnie całować. Gdy powiedziałam dwukrotnie «NIE», nadal się nie poddawał i po 2 godzinach osiągnął swój cel"73 [Diana, Egipt, 235].

„No tak, stało się to, co stać się musiało i było to bardzo przyjemne. Pamiętam, że jeszcze go tej nocy obserwowałam, gdy śpi, tę cudowną młodą twarz i wspaniałe ciało - dar od Boga, myślałam"74 [Mirijam, Tunezja, 60].

Szczególnie ciekawy wydaje się opis drugiej sytuacji, w której doszło do zbliżenia, gdyż przypomina typową baśniową narrację. Wpisuje się zatem w oba wątki narracyjne - romantyczny i orientalistyczny.

Omijanie opisu sfery seksualnej wydaje się mieć jeden zasadniczy powód. Nie pasuje do klimatu opowieści, które utrzymane są w narracji miłości romantycznej. W niej właśnie przywiązanie do drugiej osoby czy wysublimowane uczucia dominują nad fizycznością związaną z życiem seksualnym ${ }^{75}$. Nie oznacza to, że nie ma zachodnich turystek, które nie przyjeżdżają do państw muzułmańskich (czy innych państw globalnego Południa) w celach seksualnych, jednak w ich przypadku dominuje motywacja instrumentalna oparta na zasadach wymiany ekonomicznej (seks za pieniądze), której świadome są obie strony. W przypadku kobiet, które są autorkami opowieści na portalu „1001 Geschichte”, nie ma mowy o obopólnej świadomości - zdecydowana większość autorek zaangażowała się w relację o charakterze emocjonalnym, w której sfera erotyczna była dopełnieniem, a nie kwintesencją.

Co więcej, zdecydowana większość z nich nie przyjechała do państwa muzułmańskiego z zamiarem nawiązania relacji intymnej z lokalnym mężczyzną. Według badania Franziski Tschanz-Kassem wśród szwajcarskich turystek w Hurghadzie seks był istotnym motywem wyjazdu dla mniej niż $5 \%$ badanych kobiet ${ }^{76}$. Kobiety nawiązywały relacje z lokalnymi mężczyznami spontanicznie. Podobnie autorki opowieści z portalu „1001 Geschichte” zdawały się często zaskoczone swoimi uczuciami.

\footnotetext{
73 „Ein paar Tage später brachte er mich in eine Wohnung. Er saß schüchtern vor mir und irgendwann fing er an mich zu küssen. Nachdem ich zwei Mal «NEIN» gesagt hatte gab er aber immer noch nicht auf und schaffte es dann nach 2 Stunden an sein Ziel".

74 „Naja es kam was kommen musste, und es war total nett. Ich weiss noch dass ich ihn in der Nacht beobechtete wie er da schlief, dieses wunderschoene junge Gesicht, der toller Körper - ein Gottesgeschenk dachte ich".

75 A. Giddens, op.cit., s. 40.

${ }^{76}$ F. Tschanz-Kassem, op.cit., s. 42.
} 
Opisywały je jako miłość od pierwszego wejrzenia - nawiązując do jednego z kanonów zachodniego wzorca miłości romantycznej ${ }^{77}$ :

„Gdy byliśmy na otwartym morzu i późnym wieczorem po jedzeniu wyszłam jeszcze na pokład, aby zaczerpnąć świeżego powietrza, stanął nagle za mną. Po prostu obrócił mnie do siebie, wziął $\mathrm{w}$ ramiona i namiętnie pocałował. Zawsze byłam raczej odporna, ale w tym momencie sama się nie poznałam. Zakochałam się po uszy. Wspólne godziny na statku były najpiękniejsze w moim życiu"78 [Marion, Tunezja, 47].

„Sajid, Tunezyjczyk, wysoki mężczyzna, uprzejmy, inteligentny, usłużny, pracowity. Taki jak mężczyzna marzeń. Oto stał przede mną, a ja od razu się zakochałam"79 [Britta, Tunezja/ Niemcy, 36].

Warto w tym miejscu dodać, że opisywany Sajid był jednym z nielicznych mężczyzn, w którym kobieta dostrzegła nie tylko wygląd fizyczny i sposób zachowania, ale również inteligencję. Słowo to (we wszelkich możliwych formach) pojawia się w 205 opowieściach zaledwie cztery razy. To rówież potwierdza romantyczny charakter nawiązywanych relacji.

\section{Muzułmanin?}

Zdecydowana większość opisywanych mężczyzn to muzułmanie (choć zdarzyło się kilku chrześcijan z państw Bliskiego Wschodu). Biorąc pod uwagę negatywny stereotyp dotyczący pozycji kobiet w islamie, można było się spodziewać, że kobiety poświęcą religii muzułmańskiej sporo miejsca, zwłaszcza że determinizm religijny mógłby stanowić świetne wytłumaczenie niepowodzenia ich związku.

77 V. Hefner, op.cit., s. 22.

78 „Als wir dann auf hoher See waren und ich spät am Abend nach dem Essen noch an Deck ging, um etwas frische Luft zu schnappen, stand er plötzlich hinter mir. Er drehte mich einfach zu sich um, nahm mich in die Arme und küsste mich leidenschaftlich. Ich war eigentlich immer eher ein robuster Typ und erkannte mich in diesem Moment selbst nicht mehr. Ich verliebte mich Hals über Kopf. Die gemeinsamen Stunden auf dem Schiff waren die schönsten meines Lebens".

79 „Saijd, Tunesier, toller Mann, charmant, intelligent, zuvorkommen, fleißig. Eben so, wie man sich den Mann seiner Träume immer vorgestell hat. Da stand er nun vor mir und ich verliebte mich sofort". 
Tymczasem religia pojawia się stosunkowo rzadko w wypowiedziach kobiet. Być może wynika to $\mathrm{z}$ tego, że islam nie pasuje do romantycznej opowieści ${ }^{80}$. Tylko jedna autorka jednoznacznie piętnuje religię muzułmańską:

„Byłam już za bardzo zakochana i nie miałam pojęcia o prawdziwej mentalności Arabów czy muzułmanów"81 [Mirva, Liban/Niemcy, 161].

Nawiązania do religii - podobnie jak do seksu - pojawiają się rzadko, a jeżeli w ogóle - pełnią wówczas funkcję informacyjną, ilustrując nastawienie do danej kwestii moralnej, np. seksu przed ślubem:

„Od tego czasu często się spotykaliśmy, również sam na sam, potajemnie, gdy nikt nas nie widział i kiedyś (jak można by inaczej oczekiwać) doszło do niesamowicie dobrych pocałunków i trochę więcej (żadnego seksu! Habibi jest muzułmaninem)"'82 [Lari, Egipt, 256].

„Coś takiego może wydarzyć się najpewniej tylko w moim wieku, że gdy mężczyzna jest wierzącym muzułmaninem, całkowicie odrzuca seks przedmałżeński”83 [Zahra, Egipt, 293].

Odniesienia do islamu w kontekście seksu przedmałżeńskiego podkreślają religijność bliskowschodnich kochanków (choć w drugim cytacie chodzi najpewniej o jego wyrachowanie - po prostu nie miał ochoty na seks ze starszą kobietą). Stopień religijności można również wysondować, odnosząc się do spożywania alkoholu. W tym sensie kobiety powielają pewien utarty sposób myślenia, w którym spożywanie alkoholu przez muzułmanina ma być wskaźnikiem małej religijności (a więc domyślnie większej otwartości na idee zachodnie) ${ }^{84}$.

Drugą kategorię tekstów, w których można odnaleźć nawiązania do islamu, stanowią opisy ekspresji emocjonalnej bliskowschodnich kochanków. Choć większość

80 Tymczasem religia stanowiła jeden z kluczowych tematów dyskusji na polskich forach poświęconych turystyce romantycznej w Egipcie i Tunezji. Więcej na ten temat por. K. Górak-Sosnowska, Muslim or beznesman? Polish female romance tourists on religion and religiosity of their Middle Eastern partners, referat wygłoszony na konferencji „Ends and beginnings - EASR 2012 Annual conference”, Soderntorn Hogskola, Stockholm, 23-26.08.2011.

${ }^{81}$ "Ich war schon $z u$ verliebt und hatte auch keine Ahnung von der wirklichen Mentalität eines Arabers oder Moslems".

82 „Von da an haben wir uns öfters getroffen, auch alleine, heimlich wenn es niemand gesehen hat und irgendwann (wie konnte man es anders erwarten) kam es zu unheimlich guten Küssen und ein bisschen mehr (kein Sex! Habibi ist ja Moslem)".

83 „So etwas passiert vermutlich in meinem Alter nur, wenn der Mann ein gläubiger Moslem ist, der Sex außerhalb der Ehe völlig ablehnt".

${ }^{84}$ Ibidem. 
z nich używa do tego innych areligijnych metod, niektórzy, wyznając swoje uczucia, powoływali się na religię (co Niemki opisywały z niejaką ironią):

„(Czego M. mi nie przyrzekał na Allaha, myślę, że przez te fałszywe obietnice nie wejdzie do raju)" ${ }^{\prime 85}$ [Blackwomen, Egipt 189].

„Wyjął Koran z szafy i przysiągł: kocham cię z całego serca i chcę, abyś była szczęśliwa. Allah jest moim świadkiem. Byłam głęboko poruszona i zdecydowałam, że mu zaufam" ${ }^{36}$ [Bobo, Egipt, 100].

Wydaje się, że powoływanie się na Allaha czy Koran miało dodać wyznaniom dramaturgii i autentyczności, ale przede wszystkim wpisać się w stereotypowe postrzeganie świata islamu. Muzułmanie postrzegani są jako osoby wyjątkowo religijne, w związku z tym używają retoryki religijnej, aby wpisać się w ten stereotyp i zdyskontować go dla swoich potrzeb. O ile bowiem trudniej byłoby sobie wyobrazić poznanego na wakacjach kochanka, który wyznaje swoją miłość przyrzekając na Biblię.

\section{Podsumowanie}

Miłość romantyczna jest wytworem ukształtowanych kulturowo oczekiwań87. W przypadku narracji z portalu „1001 Geschichte” oczekiwania te osadzone są w kulturze zachodniej, przy czym dotyczą one dwóch odrębnych sfer - stereotypowych wyobrażeń na temat miłości romantycznej oraz postrzegania Bliskiego Wschodu i islamu.

Wydaje się, że kobiety w dużej mierze świadomie utrzymywały swoje narracje w klimacie utrwalonych w kulturze popularnej klisz dotyczących miłości i romansu. W ten sposób mogły budować i stopniować napięcie, a także zapewnić swoim opowieściom odpowiednią dawkę dramatyzmu ${ }^{88}$. Ich opowieści są bardzo plastyczne i emocjonalne, a zarazem krótkie (kilka stron znormalizowanego maszynopisu), przez co

85 „(Was M. alles auf Allah geschworen hat, ich glaube, der kommt bei diesen falschen Schwüren nie in das Paradies)".

${ }^{86}$ „Er holte den Koran aus dem Schrank und schwor: Ich liebe Dich von ganzem Herzen und will Dich glücklich machen. Allah ist mein Zeuge. Ich war tief gerührt und beschloss ihm zu vertrauen".

87 E. Illouz, Consuming the Romantic Utopia..., op.cit., s. 169.

${ }^{88} \mathrm{Na}$ dramatyzm wskazują chociażby tytuły opowieści: Dla mojej miłości byłam jedynie środkiem do celu (Für meine große Liebe war ich nur Mittel zum Zweck; Nicole, Tunezja, 4); Marzenie o wielkim szczęściu rozpadło sie na tysiąc kawałków (Der Traum vom großen Glück zerbrach in tausend Scherben; Tanja, Tunezja, 6); Polujac na kobiety w internecie (Auf Frauenjagd im Internet; Susanne 1004, Turcja, 113) etc. 
można odnieść wrażenie, że czyta się raczej krótkie opowiadania utrzymane w stylu romansu dla kobiet aniżeli biografie. Trudno stwierdzić, w jakim stopniu sposób narracji wynika z jej przedmiotu, albowiem - jak stwierdza Eva Illouz - osoby opowiadające o swoich doświadczeniach romantycznych stosują siatkę pojęciową ukształtowaną przez kulturę popularną, przy czym robią to w sposób świadomy (innymi słowy, niekoniecznie wierzą, że ich historia miłosna wyglądała „jak na filmie”, ale tak ją opisują) ${ }^{89}$. Może jest jednak i tak, że autorki opowieści trzymają się tak mocno stylistyki romansu, by jak najbardziej plastycznie i wiernie oddać charakter marzeń i nadziei, jakie miały w związku z nawiązaniem relacji intymnej.

Co ciekawe, stereotypowe wyobrażenia na temat Bliskiego Wschodu i jego mieszkańców pojawiają się w opowieściach stosunkowo rzadko. Choć bezness - czyli nawiązywanie relacji romantycznej w celu osiągnięcia korzyści finansowych - postrzegany jest przez autorów serwisu „1001 Geschichte” jako właściwy głównie dla Orientu, a i większość opowieści pochodzi z państw Bliskiego Wschodu, kulturowy determinizm jest $\mathrm{w}$ zasadzie nieobecny w narracjach. Jest to o tyle ciekawe, iż to właśnie egzotyka - zarówno miejsca, jak i osób - sprawia, że kobiety decydują się na nawiązanie bliższej relacji z nowo przecież poznanym, obcym mężczyzną. Orient i podróż do niego wydają się jednak tworzyć raczej scenerię niż esencję relacji - nawet jeżeli bez nich najpewniej by do niej nie doszło.

\section{Literatura}

Giddens A., The Transformation of Intimacy. Sexuality, Love and Eroticism in Modern Societies, Stanford University Press, Stanford 1992.

Górak-Sosnowska K., Muslim or beznesman? Polish female romance tourists on religion and religiosity of their Middle Eastern partners, referat wygłoszony na konferencji „Ends and beginnings - EASR 2012 Annual conference", Soderntorn Hogskola, Stockholm, 23-26.08.2011.

Górak-Sosnowska K., Klimiuk M., Romans czy rodzina? Małżeństwo urfi a wyobrażenia o im zachodnich turystek $w$ Egipcie, „InterAlia. Pismo poświęcone studiom queer” 2013, nr 8, s. 201-213.

Grzegorek M., Przemiany intymności w refleksji socjologicznej. Turystyka Polek w Egipcie jako poszukiwanie miłości, niepublikowana praca magisterska, Instytut Socjologii UW, Warszawa 2010.

${ }^{89}$ Ibidem, s. 189-190. 
Hefer V., From Love at First Sight to Soul Mate: Romantic Ideals in Popular Films and their Association with Young People's Beliefs about Relationships, niepublikowana praca doktorska, University of Illinois at Urbana-Champaign, Urbana 2011.

Herold E., Garcia R., DeMoya T., Female Tourists and Beach Boys. Romance or Sex Tourism?, „Annals of Tourism Research” 2001, Vol. 28, Nr 4.

Illouz E., Consuming the Romantic Utopia. Love and the Cultural Contradictions of Capitalism, University of California Press, Berkeley 1997.

Illouz E., Why Love Hurts. A Sociological Explanation, Polity Press, Cambridge 2012.

Jacobs J., Have sex will travel: romantic 'sex tourism' and women negotiating modernity in the Sinai, „Gender, Place \& Culture” 2009, Vol. 16, Nr 1.

Pruitt D., LaFont S., For love and Money. Romance Tourism in Jamaica, „Annals of Tourism Research"1995, Vol. 22, Nr 2, s. 243.

Scott J., Selwyn T., Introduction. Thinking through Tourism - Framing the Volume, w: Thinking through Toursim, red. J. Scott, T. Selwyn, Berg, Oxford 2010.

Tschanz-Kassem F., Bezness in Hurghada, niepublikowana praca magisterska, Schweizerische Tourismusfachschule, Siders 2007.

Williams L., Skin Flicks on the Racial Border. Pornography, Exploitation and Interracial Lust, w: Porn Studies, red. L. Williams, Duke University Press, London 2004.

\section{Between Romance and Orientalism: A Thousand and One Love Stories}

The paper describes the phenomenon of romance tourism through the narratives taken from the German Internet portal 1001-Geschichte.de. Romance tourism is a term used to characterize women who during holidays in the countries of global south engage in a personal relationship with a local man. As that relationship is emotional in character it cannot be limited to simple sex tourism. The German portal connects women whose feeling were abused by local man. The stories they share are consistent with narrative structures used for describing romantic love in the Western culture. However, due to the specific context, exotic environment and different cultural background of the lover, those stories are all examples of Saidian orientalism. Those dimensions form the subject of the present paper.

Keywords: romance tourism, Egypt, orientalism 


\section{Entre le romance et l'orientalisme: mille et une histoires d'amour}

Le document décrit le phénomène du "romance tourisme" à travers les récits tirés de l'un des portails allemands. Le "romance tourisme" est un terme utilisé pour caractériser les femmes qui pendant leurs vacances dans les pays du Sud s'engagent à des relations personnelles avec des autochtones. Ces relations ne peuvent pas être limitées au tourisme sexuel car elles comprennent des émotions fortes. Le portail allemand relie les femmes blessées émotionnellement. Leurs histoires partagées sont compatibles avec les structures narratives utilisées pour décrire l'amour romantique dans la culture occidentale. En outre, ces histoires sont des exemples de orientalisme Saidian en raison du contexte spécifique, de l'environnement exotique et des origines culturelles différentes de l'amant.

Mots-clés: le "romance tourisme", l'Egypte, l'orientalisme

\section{Между романтикой и ориентализмом. Тысяча и одна история о любви}

Статья указывает явление романтического туризма по рассказам из немецкого интернет-портала 1001-Geschichte.de. Романтический туризм относится к женщинам, которые во время отдыха в странах глобального Юга вступают в интимные отношения с местными мужчинами. Эти отношения носят эмоциональный характер и затем не входят в относительно простую дефиницию секс-туризма. Немецкий портал объединяет женщин, чувствами которых злоупотребили вышеупомянутые местные мужчины. Описанные истории вписываются в структуры повествования, относящиеся к романтической любви в западной культуре. В то же время, из-за специфического контекста - экзотической природы и культурной непохожести любовников, - являются примером саидовского ориентализма. Оба этих измерения, романтика и ориентализм, стали предметом этой статьи.

Ключевые слова: романтический туризм, Египет, ориентализм 